Editorial

\title{
Casting a Wider Net: Understanding the "Root" Causes of Human-Induced Soil Erosion
}

\author{
Michele A. Whitecraft ${ }^{1, *}$ and Bruce E. Huggins Jr. ${ }^{2}$ \\ 1 Department of Education, Mansfield University, Mansfield, PA 16933, USA \\ 2 Alderhollow Gardens, South Plymouth, NY 13844, USA; E-Mail: huggins@roadrunner.com \\ * Author to whom correspondence should be addressed; E-Mail: maw323@cornell.edu; \\ Tel.: +1-570-662-4564; Fax: +1-570-662-4364.
}

Received: 14 June 2013; in revised form: 15 August 2013 / Accepted: 27 August 2013 /

Published: 25 September 2013

\begin{abstract}
Although science has helped us to identify and measure the threat of soil erosion to food production, we need to cast a wider net for effective solutions. Honest assessment suggests, in fact, that this kind of eco-agri-cultural issue exceeds the traditional boundaries of scientific interest. The issue of soil erosion spills out so many ways that it demands a holistic interdisciplinary approach. In this paper we explore a systems "in context" approach to understanding soil erosion built upon the interplay of Aristotle's virtues of episteme, techne, and phronesis. We model the synergy of collaboration, where diverse ways of knowing, learning and being in the world can offer proactive soil conservation strategies - those that occur from the inside-out-instead of reactive policies, from the outside-in. We show how positivist scientific attitudes could well impede conservation efforts insofar as they can inhibit educational pedagogies meant to reconnect us to nature. In so doing, we make the ultimate argument that disparate fields of knowledge have much to offer each other and that the true synergy in solutions to soil erosion will come from the intimate interconnectedness of these different ways of knowing, learning and being in the world.
\end{abstract}

Keywords: soil erosion; episteme; techne; phronesis; practical wisdom; integrative education; transformative education; experiential education; soil health 


\section{Introduction}

Although science has helped us to identify and measure the threat of soil erosion to food production, we need to cast a wider net for effective solutions (since the world gets $99.7 \%$ of its food calories from land and less than $0.3 \%$ from the ocean and other aquatic sources [1,2], truly "casting a wider net" is a fitting metaphor here). Honest assessment suggests, in fact, that this kind of eco-agri-cultural issue exceeds the traditional boundaries of scientific interest. The issue of soil erosion spills out so many ways that it demands a holistic interdisciplinary approach.

Accordingly, we, a scientist who is also a teacher and a farmer who is also a scholar, explore a systems "in context" approach to understanding soil erosion built upon the interplay of Aristotle's virtues of episteme, techne, and phronesis - roughly understood as the theoretical "know why" of science, the technical "know how", and the practical knowledge and ethics [3]. Through this paradigm we endeavor to round out the literature and till some practical wisdom, some prudence, into the technical discussion. We also model the synergy of collaboration, where diverse ways of knowing, learning and being in the world can offer proactive strategies - those that occur from the inside-out - instead of reactive policies, from the outside-in. We believe this approach supplies us with soil-conservation solutions superior to those generated through the linear and reductive modes of traditional science, rightfully respected, but not well-matched to our problem. In fact, positivist scientific attitudes could well impede conservation efforts here insofar as they can inhibit educational pedagogies meant to reconnect us to nature. We instead cast beyond science alone in order to foster a more pro-active interdependence and understanding of the foundation of life - soil. In so doing, we make the ultimate argument that disparate fields of knowledge have much to offer each other and that the true synergy in solutions to soil erosion will come from the intimate interconnectedness of these different ways of knowing.

\subsection{Aristotelian Framing}

A scientific consensus holds that overconsumption, population growth, and the use of faulty technologies within inappropriate socio-political-economic arrangements servicing that consumption, are fast destroying humanity's natural capital [4]. Science determines this, but as well, all science is done within these same insufficient arrangements, and so it seems reasonable to incorporate politically and economically attuned sociological knowledge in the study of human-induced problems of soil degradation. Therefore, we chose to frame this paper using Flyvbjerg's seminal piece, Making Social Science Matter [3], where he elaborates on the writings of Aristotle's intellectual virtues outlined in The Nicomachean Ethics. He summarizes the three virtues as follows:

Episteme: Scientific knowledge. Universal, invariable, context-independent. Based on general analytical rationality. The original concept is known today from the terms "epistemology" and "epistemic".

Techne: Craft/art. Pragmatic, variable, context-dependent. Oriented toward production. Based on practical instrumental rationality governed by a conscious goal. The original concept appears today in terms such as "technique", "technical", and "technology". 
Phronesis: Ethics. Pragmatic, variable, context dependent. Oriented toward action. Based on practical value-rationality. Deliberation about values with reference to praxis. The original concept has no analogous contemporary term. [Terms that are similar are "applied ethics" or "policy studies"].

As Aristotle noted, working with people is not the same as manipulating experimental apparatuses; choosing practical actions for the human realm requires a different kind of thinking than one employed for making such choices in the mechanical realm. Techne is the proper rationality for developing knowledge to determine actions that deal with the physical realm; phronesis is the proper rationality for developing knowledge to determine actions (praxis) that deal with people [5]. Science, in this respect, is about techne for sure. Human-induced soil degradation is about people, hence phronesis. The best solutions to soil erosion in general, we believe, will come from the synergy of the interplay of the three.

\subsection{Background Terminology}

Episteme, a seemingly quiet, objective word, is presently a space of much political contention. Though the word "epistemology" is derived from episteme, it no longer means only one kind of knowing (i.e., a state of mind capable of demonstrating what is known through the scientific method). Today it is used in a broader sense as in, for example, "feminist epistemology" and "constructivist epistemology." Pressley's ([6], p. 3) description of feminist epistemology exhibits that broader sense and the pressure that it puts onto our sense of knowledge:

Feminist epistemology is concerned with "whose knowledge" is being considered. Feminist epistemologists critique traditional epistemology and argue for ways of understanding knowledge that focus on context and situation. Feminist epistemologists do not suggest that empirical evidence is wrong, but rather that it is necessary to understand that most beliefs are as much a result of their social context as they are factually true. The particulars of knowledge construction are the main focus for feminist epistemologists, rather than universal circumstances for justifying knowledge. These philosophers are often working on undertakings that are political in addition to intellectual.

The kind of knowledge Aristotle calls the episteme is what this description refers to as "empirical evidence", which to a researcher is that which is directly observed with the senses in a systematic process of inquiry known as the scientific method [7]. However, in a different context "empirical" can simply mean "experience"; even experiences absent of "controls" and "treatments". In matters that involve the human decision-making scientism falls short. The principles of rational inquiry do not always apply to choices people make, yet that does not mean that they are erroneous or inferior (think about love and altruism; think about dreams so big that facts don't matter). People are different and the universal, context-independent rules of episteme are not the proper rationality for assessing the human condition and motivations. So why are scholars so afraid to incorporate other ways of knowing into finding solutions to human-induced problems?

\section{Historical Perspective}

The answer seems likely tagged to cultural context. The cultural framework of western science sets itself up as universal, but it is really carved out in opposition to other ways of knowing the world and 
underscored by human politics. For instance, in the book, The Truth About Stories, King [8] contrasts the Christian story of creation with the Native American story of creation: the elements in Genesis create a particular universe governed by a series of hierarchies - God, man, animals, plants - that celebrate law, order and good government, while our Native American story, the universe is governed by a series of co-operations - animals and humans celebrating equality and balance. He then argues that the Genesis story creates a tone of competiveness, whereas with the Native story the world is at peace, and the pivotal concern is not with the ascendancy of good over evil but with the issue of balance. King ([8], pp. 23-24) continues:

So here are the choices: a world in which creation is solitary, individual act or a world in which creation is a shared activity; world that begins in harmony and slides toward chaos or world that begins in chaos and moves toward harmony; a world marked by competition or a world determined by co-operation. You recognize this pairing is a dichotomy, the elemental structure of Western society. And cranky old Jacques Derrida notwithstanding, we do love our dichotomies. Rich/poor, white/black, strong/weak, right/wrong, culture/nature, male/female, written/oral, civilized/barbaric, success/failure, individual/communal. We trust easy oppositions. We are suspicious of complexities, distrustful of contradictions, fearful of the enigmas.

Not unlike the Genesis act of creation, science is often portrayed as a solitary, individual act [9]. Moreover, formed within this dualistic model, science historically has occupied (or been occupied by) the same side of the duality where King locates western values in general. Pressley ([6], p. 5) echoes King's argument when she discusses the politically tuned consequences of dualistic thinking around which western conceptions of "knowledge" are built. She says:

Western philosophy is built around the idea of binary oppositions such as reason/emotion, mind/body, universal/particular, objective/subjective, and male/female. These are typically hierarchical with the first term given privilege. This dualistic thinking has led to the association of maleness with reason, mind, objectivity, and universals while femaleness is associated with emotion, body, subjectivity, and particulars. Feminist scholars often argue that these dichotomies create one type of knowledge that is masculine. These theorists argue that the period for singular methodology and theory has passed, and it is time to incorporate new standpoints into our way of understanding truth.

Perhaps, ironically, the singular methodology and perceived superiority of the scientific method grew from the stories that have lived in our communal subconscious - stories that smothered our desire for connectedness and communion even as they enacted the social, human element of all our thinking [7]. Perhaps, even if these genesis-type stories were not our own, they are the stories that infused our mainstream science, and what we do as scientists is validated within their paradigm [10].

Regardless, those so inculcated in the scientific method, may feel extremely uncomfortable embracing other ways of knowing (recall the heresy of those who went against the dominant culture and embraced a heliocentric universe). Alternatively, others may find it refreshing as they may intuitively realize that multiple views and different ways of knowing provide the most objective insights into any phenomena as Nietzsche [11] suggests: "There is only a perspective seeing, only a perspective "knowing"; and the more affects we allow to speak about one thing, the more eyes, different eyes, we can use to observe one thing, the more complete our "concept" of this thing, our 
"objectivity", be (emphasis in original)." One can actually see a shift in the episteme towards this notion of integrated perspectives play out in the evolution of agricultural practices, to which we next turn.

\section{Toward a More Holistic Approach}

In the past, soils were checked for their chemical content and the plant was fed with chemicals [12]. Typically, to offset nutrient losses erosion inflicts on crop production, large quantities of fertilizers were applied [2]. Narrowly considered, it seems like an efficient process, driven by objective numbers. Widen the assessment, however, and it is clearly not so efficient. Those fertilizers are fossil-fuel based and thus caught up in planet-wide competition over these resources; they pollute and disrupt ecosystems; and recent scientific findings strongly suggest that these methods do not even support the ways plants best access nutrients [13-15]. Ultimately, this type of agricultural practice is unsustainable. Now, many farmers and researchers are trying to understand the whole picture, which includes caring about the environmental effects and the sources of material input, including the politics, economics, and sociological consequences. It also includes a better understanding of the fungal and bacterial life that is essential to nourishing healthy plant life. Chemical fertilizers do not create these ideal conditions. Instead, we are now looking at more naturally available, biological inputs. For example, farmers can plant a tillage radish (Figure 1) to penetrate compacted soil allowing for better water storage and less run off [16]. Likewise, instead of adding fertilizers to enhance phosphorus we can now work to create the conditions necessary for mycorrhizal fungi to flourish and support phosphorus uptake [13].

Figure 1. Left: degraded soil with low organic matter; Right: same soil type with different management resulting in greater soil health. The tillage radish provides a biological method to breakup compaction, add organic matter and store nutrients for the spring. With permission to publish photos from Dorn Cox, University of New Hampshire.

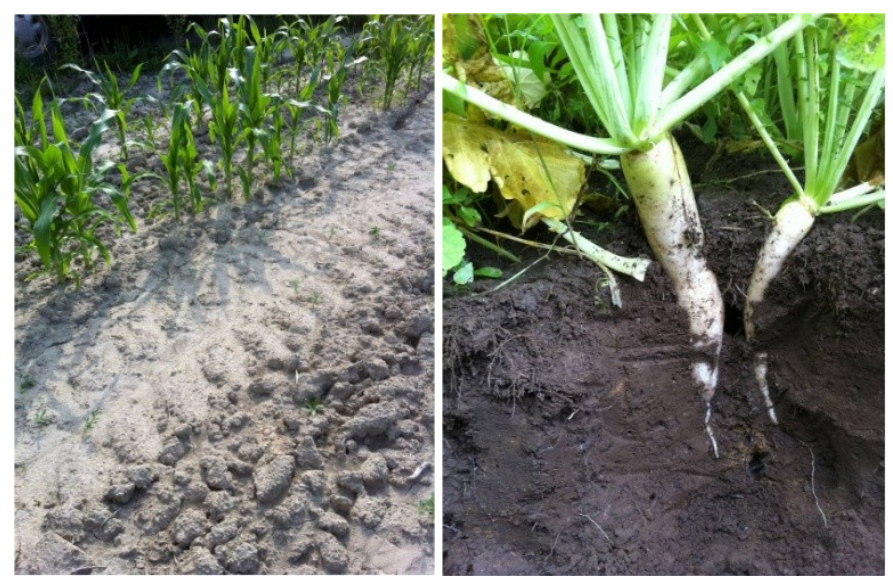


The following diagram (Figure 2) depicts the holistic approach upon which the synergy of science, technology and practical wisdom merge to develop sustainable soil conservation practices.

Figure 2. Holistic approaches honor the interconnectedness of dynamic systems and enable synergistic solutions.
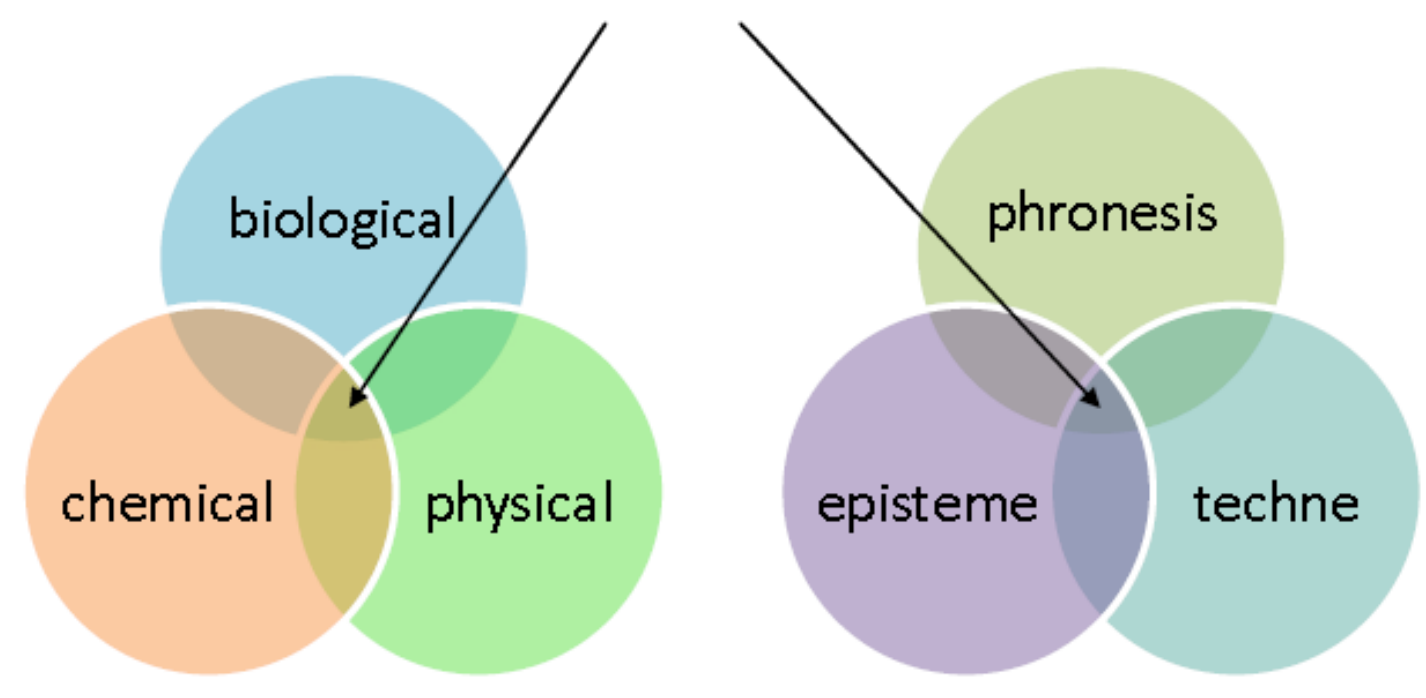

This holistic approach is part of the Cornell Soil Assessment protocol. Researchers at Cornell have devised an holistic approach that addresses the biological, chemical and physical aspects of soil health, together. On the next page (Table 1), we provide an example of Cornell's suggested management strategies for addressing soil health constraints. Although a holistic approach that assesses the interconnectedness of each component may be more practical with developed countries, developing countries may rely on the same principles through an intimate relationship with an earth whose life-giving properties are treated with respect and appreciation. Despite a lack of episteme (know why), or a techne (technology to accomplish "know how"), all of us can use the phronesis (practical wisdom, ethics, and prudence) that evolves through the intimate experience and relationship with nature. Next we look at how a positivist scientific attitude can impede conservation efforts, how technology in the absence of phronesis contributes to the problem and how education interventions involving phronesis can re-connect us to nature and foster a more proactive interdependence and understanding of the foundation of life- - soil.

Table 1. Suggested management strategies for soil health constraints [14].

\begin{tabular}{ccc}
\hline & Short Term or Intermittent & Long Term \\
\hline Physical Concerns & Fresh organic materials & \\
Low aggregate stability & Reduced tillage, surface mulch, rotation \\
& $\begin{array}{c}\text { (shallow-rooted cover/rotation } \\
\text { crops, manure, green clippings) } \\
\text { Low available }\end{array}$ & Stable organic materials \\
water capacity & (compost, crop residues high in & Reduced tillage, rotation with sod crops \\
& lignin, biochar) & \\
\hline
\end{tabular}


Table 1. Cont.

\begin{tabular}{|c|c|c|}
\hline & Short Term or Intermittent & Long Term \\
\hline \multicolumn{3}{|l|}{ Physical Concerns } \\
\hline High surface density & $\begin{array}{l}\text { Limited mechanical soil loosening } \\
\text { (e.g., strip tillage, aerators); } \\
\text { shallow-rooted cover crops, } \\
\text { bio-drilling, fresh organic matter }\end{array}$ & $\begin{array}{l}\text { shallow-rooted cover/rotation crops; } \\
\text { avoid traffic on wet soils; } \\
\text { controlled traffic }\end{array}$ \\
\hline High subsurface density & $\begin{array}{l}\text { Targeted deep tillage (zone } \\
\text { building, etc.); deep rooted } \\
\text { cover crops }\end{array}$ & $\begin{array}{l}\text { Avoid plows/disks that create pans; } \\
\text { reduced equipment loads/traffic on } \\
\text { wet soils }\end{array}$ \\
\hline \multicolumn{3}{|l|}{ Biological Concerns } \\
\hline $\begin{array}{l}\text { Low organic } \\
\text { matter content }\end{array}$ & $\begin{array}{l}\text { Stable organic matter (compost, } \\
\text { crop residues high in lignin, } \\
\text { biochar); cover and rotation crops }\end{array}$ & Reduced tillage, rotation with sod crops \\
\hline Low active carbon & $\begin{array}{c}\text { Fresh organic matter } \\
\text { (shallow-rooted cover/rotation } \\
\text { crops, manure, green clippings) }\end{array}$ & Reduced tillage, rotation \\
\hline $\begin{array}{l}\text { Low mineralizable } \mathrm{N} \\
\quad(\text { Low PMN })\end{array}$ & $\begin{array}{l}\text { N-rich organic matter (leguminous } \\
\text { cover crops, manure, } \\
\text { green clippings) }\end{array}$ & $\begin{array}{l}\text { Cover crops, manure, rotations with } \\
\text { forage legume sod crop, reduced tillage }\end{array}$ \\
\hline High root rot rating & $\begin{array}{l}\text { Disease-suppressive cover crops, } \\
\text { disease breaking rotations }\end{array}$ & $\begin{array}{l}\text { Disease-suppressive cover crops, disease } \\
\text { breaking rotations, IPM practices }\end{array}$ \\
\hline Chemical concerns & $\begin{array}{l}\text { See also soil fertility } \\
\text { recommendations }\end{array}$ & \\
\hline Unfavorable $\mathrm{pH}$ & $\begin{array}{l}\text { Liming materials or acidifier } \\
\text { (such as sulfur) }\end{array}$ & Repeated applications based on soil tests \\
\hline $\begin{array}{l}\text { Low } \mathrm{P}, \mathrm{K} \text { and Minor } \\
\text { elements }\end{array}$ & $\begin{array}{l}\text { Fertilizer, manure, compost, } \\
\text { P-mining cover crops, } \\
\text { mycorrhizae promotion }\end{array}$ & $\begin{array}{l}\text { Application of } \mathrm{P}, \mathrm{K} \text { materials based on } \\
\text { soil tests; increased application of } \\
\text { sources of organic matter; reduced tillage }\end{array}$ \\
\hline High salinity & Subsurface drainage and leaching & $\begin{array}{l}\text { Reduced irrigation rates, low-salinity } \\
\text { water source, water table management }\end{array}$ \\
\hline High sodium content & $\begin{array}{l}\text { Gypsum, subsurface drainage, } \\
\text { and leaching }\end{array}$ & $\begin{array}{l}\text { Reduced irrigation rates, } \\
\text { water table management }\end{array}$ \\
\hline
\end{tabular}

\section{Setbacks of Positivism (Episteme)}

Unfortunately, the strong residue of traditional positivist thinking in science can impede conservation efforts. The academy is still in the grip of that gaping and imbalanced episteme, even as we look to educational interventions to reconnect us to nature and the foundation of our life in the life of the soil. With a few notable exceptions, the kind of knowledge most valued in the academy is that which can be dealt with in a rational, linear, and controlled manner. These words, "rational", "linear", and "controlled", Palmer claims in The Heart of Higher Education, define the comfort zone in academic culture ([17], p. 36). As an academic himself, Palmer goes so far as to say that academia is sometimes governed by orthodoxy as profound as any church. Further, Palmer cites examples where formulaic thinking conceals rather than reveals the truth, and sometimes with catastrophic results. He 
mentions, among other examples, the complicity of German Higher Education in the Holocaust where the purity obsession forbade "real scholars" from engaging in the messy affairs of the world. Citing Polanyi, Palmer ([17], p. 22) says that our explicit knowing depends on a "vast subterranean layer of tacit human knowing, and we will be arrogant about the hegemony of science until we learn to honor its wordless underground foundations".

We might well heed the warning. Significantly, it comes from within science too. Advocating a further break, from our complete reliance on science as linear, objective and reductionist, Zajonc ([18], p. 81) cites Einstein and quantum mechanics:

Einstein's relativity and quantum mechanics both undermine objectification and support a relational view of reality in which phenomena are co-created by the observer and the world. Second, through entanglement and emergence, physics offers evidence for the ontological holism that grants wholes a standing long denied them. Parts are no longer privileged. These two realizations are essential to a proper philosophical infrastructure for higher education.

When it comes to soil degradation, agriculture and food scarcity, blindly following the narrow rules of a narrowly defined efficiency without more focus on resilience, sustainability, biodiversity and distributive fairness [19] will not produce sustainable results. In the same vein, the activities of financial participants in the food system have driven commodity prices away from levels justified by "market fundamentals", as the literature shows that food price speculation, not supply and demand, has played the biggest role in excessive price hikes [20-23]. Further supporting this Zajonc ([15], p. 81) writes:

As in physics, the simplifying assumptions of classical economics were made because economic theory could not handle the complexities of the real world. But are humans really rational economic actors? Economics experiments show we are not. Understanding this opens us to other important questions to consider, such as, is market behavior the only or best way to gauge preferences, or might we allow for thoughtful, patient introspection concerning the root causes of suffering and happiness? Does the market really offer an accurate and comprehensive valuation of community or might we allow for forms of fellowship that elude economic objectification?

According to Zajonc, fields of science need to re-conceive themselves according to a postreductionist paradigm in which lived experience, connection and complexity are given far more attention in the same way that economics has had to rethink its paradigms for understanding human behavior in the market [18]. Palmer ([17], p. 41) corroborates this and notes an ironic connection to pedagogy, that fundamental root zone of the academy:

Academic culture needs to embrace the simple fact that cognition, which is our business, is intimately linked to affect, no matter how much we think emotions are not our business. As neuroscientists such as Candice Pert have told us, thinking is not done solely by the brain, an organ housed in the cranium. Thinking is done by the mind, which is not an organ but a process that is distributed throughout the body and draws on every faculty we have. So when I hear faculty dismiss the affective dimension of teaching and learning as "touchy-feely stuff', I have to conclude that they are projecting their personal discomfort with emotions rather than making a statement about the real world. 
There is a pair of tragicomic ironies embedded in academic resistance to taking seriously the connection between feeling and thinking. Academics who want to factor out "subjective emotions" in favor of data based "objective knowledge" will, at the same time, blithely ignore fifty years of research about the importance of attending to the emotions if we want to liberate the mind. I do not think it unfair to say that such people are "pedagogical fundamentalists" who proof-text the research the way Biblical fundamentalists proof-text the Bible, honoring whatever supports their biases and ignoring the rest.

The paired irony is that these academics ignore all the research-based knowledge we have on the role of emotions in learning largely because embracing the implications of that knowledge would take them out of their emotional comfort zones (italics in original)! It is enough to make one's head spin. But we who advocate for integrative education ought to be spinning our heads in public, weaving a sound defense for attending to the heart-mind connection, making it more difficult for orthodox academics to be dismissive of brain science, pedagogical reality, and simple common sense.

We wholeheartedly agree that a more holistic, integrative approach to soil erosion is necessary as a complete reliance on science alone has been a major setback in soil conservation.

\section{4. "Faulty" Technology (Techne)}

As documented in "The Plow that Broke the Plains [24]", U.S. farmers (whose tools may have been considered universal and context independent), stayed with the traditional methods and technologies of tillage and decimated the Midwest during the 1930s. Similarly, if we blindly pull through our world with the traditional linear reductionist plow, without concern for system dynamics and the synergy of the interconnected whole, solutions to worldwide soil degradation will be inadequate. Currently our models are at odds with one another which further demonstrates the inadequacies of knowing all of the variables and hence, the characterization of and possible solutions to soil erosion. Consider, for example, the research Trimble [25] cites on U.S. soil erosion alone. In 2000, he cites the average annual cropland soil erosion at 2 billion [26], 4.0 billion [27-29], 4.5 billion [30], 4.8 billion [31], 5 billion [32], or 6.8 billion tons. Clearly, the range of predictions makes it difficult to use these models as tools, let alone understand the magnitude and interconnectedness of the variables involved. Trimble [25] does not mention that he is citing models from various decades, there is still great variation within a decade. Nonetheless, scientists do agree that although erosion rates in the U.S. have decreased in the past two decades [2], cropland is still losing soil faster than its sustainable replacement rate $[33,34]$. Additionally, erosion rates on U.S. rangelands remain relatively high at $6 \mathrm{t} /$ ha-year [35].

In short the models and technologies we use to understand soil erosion and soil degradation do not honor the truly complex, interconnected nature of the problem. We need to go beyond our traditional methodologies and incorporate what Brooks [36] calls an "epistemological modesty". This modest disposition begins with the recognition that there is no one method for solving problems [36]. Relying on quantitative and rational analysis gives you part of the truth, not the whole [36]. Brooks ([36], p. 246), gives this example which leads with episteme and techne, and ends with phronesis: 
If you were asked what day in the spring you should plant corn, you could consult a scientist. You could calculate weather patterns, consult the historical record, and find the optimal temperature range and date at each latitude and altitude. On the other hand you could ask a farmer. Folk wisdom in North America decrees that corn should be planted when oak leaves are the size of a squirrel's ear. Whatever the weather in any particular year, this rule will guide the farmer to the right date.

This knowledge is a different sort of knowledge. This knowledge comes from "integrating and synthesizing diverse dynamics and is produced over time, by an intelligence that is associational—observing closely, imagining loosely, comparing like to unlike and like to like to find harmonies and rhythms in the unfolding of events ([36], p. 246)". This associational intelligence can even help advance scientific knowledge, too. Honoring different ways of knowing, honoring the practitioners' intuitions and observations, can also help scientists enrich their research questions. Case in point, one particular farmer [37] has noticed for decades, that the height of a hornets' nest has served as an excellent predictor of the amount of snowfall in a particular area in upstate New York. Instead of a complete reliance on meteorology for weather prediction, might we now study animals to enhance our ability predict the weather?

In short, technology is only as good as the hand that guides it — and the guiding hand is only as wise and compassionate as the mind and heart that direct it [17]. We look next at the practical knowledge, wisdom and ethics that would have prevented, "The Plow that Broke the Plains".

\section{The Prudence of Phronesis}

"An ethical action, rightly taken, invites reciprocal generosity that can appear in unexpected ways."

-Parker Palmer

The Midwestern soil crisis of the 1930s could have been prevented, had we turned to practical wisdom and ethics, that is, had we looked at the world as a living organism (hence phronesis) as opposed to a machine (hence techne). We believe that the soil, as well as the world, should be treated as a living organism. Just as we are not simply a compilation of various cells, but a whole that is entirely different than its parts, soil is not just dirt, but a living breathing entity full of organic matter, bacteria, minerals, water and air whose whole is so much greater than the sum of its parts. We understand Barbara McClintock's Nobel winning mentality as described by Palmer ([17], p. 28):

Barbara McClintock understood her primary experimental materials not as objects but as beings. We can know a relational reality only by being in relation to it - not keeping our distance, as in the objectivist mythology, but moving close and leaning in, then testing what we know against the standard of evidence and logic in the context of the scientific community. McClintock, says one writer, "gained valuable knowledge by empathizing with her corn plants, submerging herself in their world and dissolving the boundary between object and observer."

In order for practical knowledge and wisdom to guide our actions and inform our solutions, we must realize that the "objectivity" that has dominated higher education is a myth. We now understand that there is a mutually influential relationship of the knower and the known [38] and that objectivism is no longer a viable way to frame knowing, teaching or learning, let alone policy or decision-making. 
Regardless of the field (agricultural or disciplinary), as humans, we must hold phronesis at least on equal footing as episteme and techne if we truly wish to live in a sustainable way. The practical knowledge and wisdom of practitioners must be valued. This knowledge and wisdom, borne of experience and immersion in our various fields, can truly enhance decision-making and problem solving. Consider the veteran teacher, who, in an effort to maximize learning, chooses to review a test at the end of a class instead of the beginning so that those who may have done poorly are not distracted [39]. Or, the veteran police officer who knows just what questions to ask. Case in point, when a female victim of an armed robbery was asked for a description of the burglar, she described the thief (whose face she could not see) as a "man about 5 foot 2 inches tall, wearing camouflage from head to toe [40]". Upon hearing this description, the officer had the foresight to ask what the thief did with the pocketbook. The victim said that "he put it over his shoulder and ran away". As she spoke she began to realize what she was saying and they both concluded that the culprit may have been female; since most men would just hold the purse in their hands and run away. Sure enough, the suspect, a female, was caught twenty minutes later with the camouflage clothing hidden in her car. In this case the preconceived notion that robbers are male, unknowingly added details to the description of the thief that could have inhibited the thief's apprehension. The experience and practical knowledge possessed by the officer allowed his interest to be piqued by the short stature of the culprit, and thereby formulate a question that exposed the true sex of the suspect even when the victim's brain muddled her description of what actually transpired. As cases like the above show, even before something is confirmed as "knowledge" it is still useful.

\section{Educating "Runners" for a More Transformative World}

The (not these) United States is (not are) a collective society that thinks as an individualistic one [36]. In one study, Nisbett [41] found that when asked to describe their day, American six year olds make three times more references to themselves than Chinese six year olds. Additionally, the latest trend in U.S. education has been "student-centered" learning as opposed to "teacher-centered". We disagree with the "it's all about me" attitude and subscribe to Palmer's philosophy that teaching and learning should be "subject-centered" [42] as well as experiential to nurture an empathetic, communal understanding of the interconnectedness of life. Through entering into a subject-centered, experiential education we believe that people will have greater opportunities to practice trust; a trust that may lead to compassion and sacrifice. Here is how Brooks ([36], p. 155) describes it:

Trust is habitual reciprocity that becomes coated by emotion. It grows when two people begin volleys of communication and cooperation and slowly learn they can rely upon each other. Soon members of a trusting relationship become willing to not only cooperate with each other but sacrifice for each other.

A closer look at the foundations of American education shows a "hidden curriculum" that is atomistic and competitive rather than interconnected and communal [17]. Earlier we explored Hill's suggestion whereby this philosophy of education may have its underpinnings in the stories we've been told. Regardless, we acknowledge the need for an integrative education that aims to " "think the world together' rather than 'think it apart'; to know the world in a way that empowers educated people to act 
on behalf of wholeness rather than fragmentation [17]". Like Palmer and Zajonc, we believe in a profound form of education where caring and knowing are united. In an education based on relationships where Goleman [43] finds we are "hard wired for social learning, imitating down to the level of neurons what is occurring around us". In addition, according to Zajonc [18], such imitation is formative, shaping the very cognitive, emotional, and moral faculties we use to make sense of the world. We believe in an education where we:

Attend to the cultivation of our students' humanity at least as much as we instruct them in the content of our fields. Long after they forget the content they learned, who they have become will endure and determine much of the character and quality of their contribution to society and personal satisfaction they take in life ([18], p. 102).

When we consider, that the global urban population in 2008 was at 3.3 billion people [44], more than half of all humans living on the planet, we recognize the urgency that now, more than ever, we need to create opportunities for people to have a life-sustaining relationship with the earth. This statistic stands in stark contrast to 13 percent a century ago; and 3 percent a century before that [44]. The solutions to soil degradation must come from an educated populace that learns from the interrelationship and our interconnectedness to one another and the earth, regardless of whether we live in the city or the country. Compassionate action is fostered in students when they learn not only with the intellect but also with the heart. Transformative, experiential educational opportunities must activate our feelings. For when our feelings are activated, we are moved to action [18].

Unfortunately, the technology of today can act as an obstacle to developing interpersonal skills and relationships as well as life skills and compassion in general. In the past children had to resolve many of their own conflicts as their parents were not instantly accessible (via cell phone) to help navigate a disagreement with a friend. They learned from their successes and their failures. They learned from experience. Today, many U.S. students have been reported surfing the internet and texting during class, bullying each other on social media, "googling" an answer instead of formulating one on their own, and taking pictures of the board as opposed to taking notes [39]. Additionally the advent of "all-online" degrees, suggest we have forgotten about the power of those person-to-person, face-to-face, "live encounters" that animate the human spirit in ways that nothing else can [17]. The kind of "distance education" (both spatial and affective) that objectivism breeds lays the ground for lives lived at a distance from the suffering world [17].

Conversely, technology can bring people and ideas closer together. People who live in remote locations or parents who stay home with their children, now have access to higher education and information they would not have had otherwise. Very simply, a basic tenet of toxicology - the dose makes the poison - is applicable here. What dictates whether technology will have a positive or negative effect on the human and earthly condition centers on practical wisdom and ethics. Practical wisdom - the wisdom associated with experience and thus, always, with specificity, locality — we can cause to be learned through collaborative interactions with one another and with nature. Currently, in the traditional teaching/learning paradigm we teach students about nature instead of from nature. We need to esteem experiential learning to transform our world.

To bring this paper full circle, we revisit the Native American wisdom in a letter written to the white man: 
We know that you highly esteem the kind of learning taught in those Colleges, and that the Maintenance of our young Men, while with you, would be very expensive to you. We are convinced that you mean to do us Good by your Proposal; and we thank you heartily, But you, who are wise must know that different Nations have different Conceptions of things and you will therefore not take amiss, if our ideas of this kind of Education happen not to be the same as yours. We have had some Experience of it. Several of our young People were formerly brought up at the Colleges of the Northern Province: they were instructed in all your Sciences; but, when they came back to us, they were bad Runners, ignorant of every means of living in the woods, neither fit for Hunters, Warriors, nor Counselors, they were totally good for nothing.

We are, however, not the less oblig'd by your kind offer, tho' we decline accepting it; and, to show our grateful Sense of it, if the Gentlemen of Virginia will send us a Dozen of their Sons, we will take Care of their Education, instruct them in all we know and make Men of them ([45], p. 240).

Not only did we find this letter very well crafted for what it says, we thought the wisdom in the carefully chosen words and in what it doesn't say were beautiful examples of phronesis. We doubt the white-man's letter would have been as culturally sensitive.

\section{Conclusions}

Many have called for farmer incentives to fully implement conservation methods to help save the earth's soil $[2,46,47]$. It is our hope that one day the understanding that we are part of a greater, interconnected whole will be incentive enough to want to do the right in conserving all of the earth's natural resources. Living in a sustainable way, as we have attempted to elucidate in this paper, certainly goes well beyond pecuniary incentives. Putting more money into incentives for farmers to implement conservation methods, is akin to putting more synthetic fertilizer on fields without looking at the interconnectedness of the reasons for the poor quality soil. This is why this paper sought to incorporate a more holistic understanding that incorporates how we educate our populace.

To paraphrase Albert Einstein, you cannot solve a problem with the frame of mind that created the problem. We feel the best solutions to preventing soil degradation will not come from episteme, techne or phronesis alone, but from integration of all three of Aristotle's intellectual virtues, including the non-falsifiable one. The richness of the world will not reveal itself by a single means of inquiry [18]. As Palmer [17] describes it, "genuine knowing comes out of a healthy dance between the objective and the subjective, between the analytic and the integrative between the experimental and what I would call the receptive". Some pioneers have realized this and are now beginning to offer solutions to soil erosion by looking at the interconnectedness of the chemical, physical and biological aspects of soil. Likewise we believe that the sensitivity necessary to produce wisdom, we can cause to be learned through collaborative, integrative, and experiential learning.

In the vocabulary of competition, if we continue to value knowledge over understanding, in the end soil will win. Nature-not episteme or techne-will be the final arbiter. Through phronesis we understand that. The life that springs out of soil will also return to it, us too. We just have to decide what legacy we want to leave behind, and if that legacy includes a sustainable lifestyle [48]. After all, soil erosion, soil degradation, and food scarcity are all related to epistemology: 
Every epistemology_rooted (as all of them are) in a particular ontology, and manifesting (as all of them do) in a particular pedagogy — has an impact on the ethical formation of learners. Epistemology becomes operational in students' lives not through overt conversation or explicit knowing but through modes of teaching and learning that tacitly form or deform learners in a particular way of relating to the world. An integrative pedagogy is more likely to lead to moral engagement because it engages more of the learners self and teaches by means of engagement: the curriculum and the "hidden curriculum" embedded in such a pedagogy support a way of knowing that involves much if not all of the whole self in learning about the world [italics in original] ([17], p. 32).

\section{Acknowledgments}

We wish to thank: Elaine Norris for her editorial contributions and critique of our paper; Dorn Cox from Tuckaway Farm and doctoral student at University of New Hampshire for use of his tillage radish photo; and the Cornell Soil Health Team for publishing a holistic manual on soil health.

\section{Conflicts of Interest}

The authors declare no conflict of interest.

\section{References}

1. Food and Agriculture Organization of the United Nations (FAO). Food Balance Sheet; FAO: Rome, Italy, 1998.

2. Pimentel, D. Soil erosion: A food and environmental threat. Environ. Dev. Sustain. 2006, 8, 119-137.

3. Flyvbjerg, B. Making Social Science Matter: Why Social Inquiry Fails and How It Can Succeed Again; Cambridge University Press: Cambridge, UK, 2001.

4. Ehrlich, P. Human natures, nature conservation, and environmental ethics. BioScience 2002, 52, 31-43.

5. Polkinghorne, D. Practice and the Human Sciences: The Case for a Judgment-Based Practice of Care; State University of New York Press: Albany, NY, USA, 2004.

6. Pressley, L. Whose Knowledge Is It Anyway? Feminist Epistemology and Science; University of North Carolina: Greensboro, NC, USA, 2005.

7. Whitecraft, M. Understanding the Acculturation of Women in Science: The Interplay of Episteme, Techne, and Phronesis in Retaining Females in Undergraduate Science. Ph.D. Thesis, Cornell University, Ithaca, NY, USA, 15 December 2012.

8. King, T. The Truth about Stories: A Native Narrative; University of Minnesota Press: Minneapolis, MN, USA, 2003.

9. Brotman, J.; Moore, F. Girls and science: A review of four themes in the science education literature. J. Res. Sci. Teach. 2008, 45, 971-1002.

10. Norris, E. Syracuse University, Syracuse, NY, USA. Personal communication, 2013.

11. Nietzsche, F. On the Genealogy of Morals; Vintage Books: New York, NY, USA, 1969.

12. Moebius-Clune, B. Soil as a Foundation for Health and Resilience. Presented at Cornell University, Ithaca, NY, USA, 30 April 2013. 
13. Wolfe, D. Soil as a Foundation for Health and Resilience. Presented at Cornell University, Ithaca, NY, USA, 30 April 2013.

14. Gugino, B.; Idowu, O.; Schindelbeck, R.; van Es, H.; Wolfe, D.; Moebius-Clune, B.; Thies, J.; Abawi, G. Cornell Soil Health Assessment Training Manual, 2nd ed.; NYSAES: Geneva, NY, USA, 2009.

15. Van Noordwijk, M.; Cadisch, G. Access and excess problems in plant nutrition. Plant Soil 2002, 247, 25-39.

16. Cox, D. Soil as a Foundation for Health and Resilience. Presented at Cornell University, Ithaca, NY, USA, 30 April 2013.

17. Palmer, P. The Heart of Higher Education; Jossey-Bass: San Francisco, CA, USA, 2010.

18. Zajonc, A. Attending to Interconnection: Living the Lesson. In The Heart of Higher Educaction; Jossey-Bass: Sanfrancisco, CA, USA, 2010; pp. 77-99.

19. Paul, J.; Wahlberg, K. A New Era of World Hunger? Available online: http://www.globalpolicy. org/social-and-economic-policy/world-hunger/48424.html (accessed on 10 October 2011).

20. Knaup, H.; Schiess, M.; Seith, A. Speculating with Lives: How Global Investors Make Money out of Hunger. Available online: http://www.globalpolicy.org/component/content/article/217-hunger/ 50673-speculating-with-lives-how-global-investors-make-money-out-of-hunger.html (accessed on 18 October 2011).

21. Global Policy Forum/Friedrich Ebert Foundation. Interactive Thematic Dialogue of the UN General Assembly on the Global. Available online: http:/www.globalpolicy.org/images/pdfs/ 0406gadialogue.pdf (accessed on 5 October 2011).

22. Food and Agriculture Organization. The State of Food Insecurity in the World. 2010. Available online: http://www.fao.org/docrep/013/i1683e/i1683e.pdf (accessed on 3 October 2011).

23. Organization for Economic Cooperation and Development \& FAO. Agriculture: Higher Prices Here to Stay, says OCED-FAO. Available online: http://www.globalpolicy.org/social-andeconomic-policy/world-hunger/general-analysis-on-hunger/50354-agriculture-higher-prices-hereto-stay-says-oecd-fao-report-.html?itemid=id\#1291 (accessed on 10 October 2011).

24. Lorentz, P. The Plow that Broke the Plains [Film]; Eastern Service Studios: New York, NY, USA, 1936. Available online: http://www.youtube.com/watch? $\mathrm{v}=\mathrm{fQCwhjWNcH8}$ (accessed on 18 May 2013).

25. Trimble, S. U.S. soil erosion rates-Myth and reality. Science 2000, 289, 248-250.

26. USDA. Soil and Water Resources Coservation Act: 1980 Appraisal, Part I: Soil, Water, and Related Resources in the United States: Status, Conditions and Trends and Appraisal; Part II: Soil, Water and Related Resources in the United States, Analysis of Trends; USDA: Washington, DC, USA, 1981.

27. Raven, P.; Berg, L.; Johnson, G. Environment; Saunders: Philadelphia, PA, USA, 1995.

28. Beasley, R. Erosion and Sediment Control; Iowa State University Press: Ames, IA, USA, 1972.

29. Government Accounting Office. To Protect Tomorrow's Food Supply, Soil Conservation Needs Priority; GAO: Washington, DC, USA, 1977.

30. Pimentel, D.; Harvey, C.; Resosudarmo, P.; Sinclair, K.; McNair, M.; Crist, S.; Spritz, L.; Fitton, L.; Saffouri, R.; Blair, R. Response to Crosson letter. Science 1995, 268, 464-465. 
31. Barlow, T. Soil Conservation Policies: An Assessment; Soil Conservation Society of America: Akeny, IA, USA, 1979.

32. Pimentel, D. Land degradation: Effects on food and energy resources. Science 1976, 194, 149-155.

33. USDA. Changes in Average Annual Soil Erosion by Water on Cropland and CRP Land, 1992-1997; Natural Resources Conservation Service: Washington, DC, USA, 2000.

34. USDA. Changes in Average Annual Soil Erosion by Wind on Cropland and CRP Land, 1992-1997; Natural Resources Conservation Service: Washington, DC, USA, 2000.

35. Committee on Opportunities in Agriculture, National Research Council. Frontiers in Agricultural Research: Food, Health, Environment and Communities; National Academies Press: Washington, DC, USA, 2003.

36. Brooks, D. The Social Animal; Random House: New York, NY, USA, 2011.

37. Huggins, B. Alderhollow Gardens, South Plymouth, NY, USA. Personal Communication, 2013.

38. Palmer, P. To Know as We Are Known; HarperCollins: New York, NY, USA, 1993.

39. Whitecraft, M. Cornell University, Ithaca, NY, USA. Personal Communication, 2013.

40. National Geographic. Investigation Discovery; National Geographic Channel: Washington, DC, USA, 2012.

41. Nisbett, R. The Geography of Thought: How Asians and Westerners Think Differently... and Why; Free Press: New York, NY, USA, 2003; pp. 87-88.

42. Palmer, P. The Courage to Teach: Exploring the Inner Landscape of a Teacher's Life; Jossey-Bass: San Francisco, CA, USA, 1998.

43. Goleman, D. Social Intelligence: The New Science of Human Relationships; Bantam: New York, NY, USA, 2006.

44. Ruble, B. The Challenges of the Twenty-First Century City. Presented at Fetzer-Wilson Center Seminar, Community Resilience in the Twenty-First Century, Chicago, IL, USA, 14 April 2010.

45. Carroll, A. Letters of a Nation; Broadway Books: New York, NY, USA, 1999; p. 240.

46. Department of Natural Resources. Soil and Water Conservation Program. Available online: http://dnr.mo.gov/env/swcp/ (accessed on 20 May 2013).

47. United States Government Accounting Office. Agricultural Conservation: USDA Needs to Better Ensure Protection of Highly Erodible Cropland and Wetlands, Report to the Ranking Democratic Member, Committee on Agriculture, Nutrition, and Forestry; U.S. Senate; U.S. General Accounting Office: Washington, DC, USA, 2003.

48. Pimentel, D.; Whitecraft, M.; Scott, Z.R.; Zhao, L.X.; Satkiewicz, P.; Scott, T.J.; Phillips, J.; Szimak, D.; Singh, G.; Gonzalez, D.; et al. Will limited land, water, and energy, control human population numbers in the future? Hum. Ecol. 2010, 38, 599-611.

(C) 2013 by the authors; licensee MDPI, Basel, Switzerland. This article is an open access article distributed under the terms and conditions of the Creative Commons Attribution license (http:// creativecommons.org/licenses/by/3.0/). 